\title{
STATUS KONSERVASI VEGETASI POHON DI LAHAN BERA WOMNOWI SIDEY MANOKWARI (SEBUAH CATATAN KECIL INVENTARISASI VEGETASI DI HUTAN SEKUNDER PAPUA BARAT)
}

\section{CONSERVATION STATUS OF TREES VEGETATION AT FALLOW LAND WOMNOWI SIDEY MANOKWARI (A LITTLE INVENTORY VEGETATION AT SECONDARY FOREST OF WESTERN PAPUA)}

\author{
Slamet Arif Susanto \\ Alumni Jurusan Biologi Universitas Papua, Manokwari Papua Barat Indonesia \\ kode pos 98357 \\ Korespondensi : +6285254702021 e-mail: ssarf4@gmail.com
}

\begin{abstract}
Conservation study at secondary forest, particularly at fallow land is important on the future. The purpose of this study to make a little inventory trees vegetation at fallow land Womnowi Sidey Manokwari based list of International Union for Conservation of Nature Resources (IUCN). Analysis vegetation method had use in this study a continuous strip sampling technique, $10 \times 10$ meters for sampling poles and $20 \times 20$ meters for trees on first week May 2018. Total number species trees vegetation at one hectare is 378 an individual corresponding 65 species poles and trees. The result showing trees vegetation dominate least concern (LC) status. Two species has been identified as near threatened (NT) and vulnerable (V) at poles phase respectively : Aglaia odorata Lour. (NT) and Intsia bijuga (Colebr.) Kuntze. (V). Important value index (IVI) of species on list IUCN $76.05 \%$ at poles and $83.53 \%$ on trees. Dominance of species may be influence on their conservation status, further comprehensive research require at some type fallows in Western Papua.
\end{abstract}

Key word: fallow, conservation, trees vegetation, analysis of vegetation, Manokwari

\begin{abstract}
Abstrak
Studi konservasi di hutan sekunder khususnya di lahan bera penting di masa mendatang. Penelitian ini bertujuan membuat sebuah catatan kecil inventarisasi vegetasi pohon di lahan bera Womnowi Sidey Manokwari berdasarkan data Union for Conservation of Nature Resources (IUCN). Penelitian ini menggunakan metode analisis vegetasi - sebuah teknik continuous strip sampling, $10 \times 10$ meter untuk fase tiang dan 20 × 20 meter untuk fase pohon yang dilakukan pada awal bulan Mei 2018 . Total individu jenis yang diinventarisasi pada luas satu hektar adalah 378 individu terdiri dari 65 jenis tiang dan pohon. Hasil menunjukkan vegetasi pohon didominasi oleh status LC. Dua jenis telah teridentifikasi sebagai NT dan V pada fase tiang: Aglaia odorata Lour. (NT) and Intsia bijuga (Colebr.) Kuntze. (V). Indeks nilai penting (INP) jenis yang tergolong dalam IUCN adalah $76.05 \%$ pada fase tiang dan $83.53 \%$ pada fase pohon. Jenis dominan mungkin berpengaruh pada status konservasinya, penelitian lanjutan yang komprehensif perlu dilakukan dibeberapa tipe lahan bera di Papua Barat.
\end{abstract}

Kata kunci: bera, konservasi, vegetasi pohon, analisis vegetasi, Manokwari 


\section{Pendahuluan}

Salah satu ciri khas sistem pertanian tradisional di Papua adalah daerah hutan yang bercampur dengan daerah pertanian sebagai konsekuensi dari sistem perladangan berpindah (Kartikasari et al., 2012). Hutan sekunder di Papua umumnya merupakan dampak dari sistem bera yang berpuluh-puluh tahun ditinggalkan (Allen et al., 2002), sehingga struktur vegetasi didominasi oleh vegetasi pohon. Kanopi dari vegetasi pohon dengan pola cabang tertentu mampu menciptakan iklim mikro di bawah naungan, khususnya meningkatkan kadar air tanah, meningkatkan kelembaban, dan memicu aktivitas mikroba (Budirianto, 2011). Susanto et al., 2019 menunjukkan jenis vegetasi dominan di lahan bera berumur 15 tahun Womnowi Distrik Sidey Manokwari berpengaruh pada aspek produktivitas serasah basah, sehingga diduga memengaruhi laju transfer nutrisi dari vegetasi menuju tanah. Bagaimanapun bentuk kontribusinya bagi lahan bera, vegetasi pohon di lahan berbentuk hutan sekunder, perlu diketahui status konservasinya.

Lahan bera pada dasarnya dibagi menjadi tiga model berdasarkan aspek vegetasi dominan: bera alami, bera diperkaya, dan bera diimproviasasi (Sancez, 1999). Lahan bera dengan vegetasi dominan yang sering dimanfaatkan oleh masyarakat lokal (bera diperkaya) telah teridentifikasi oleh Susanto et al., 2018 di Womnowi Sidey Manokwari. Meskipun telah teridentifikasi jenis didominasi oleh vegetasi penghasil buah seperti Lansium domesticum Correa. (lansat) dan Pometia pinnata Forst \& Forst. (matoa) (Susanto et al., 2018), masih terdapat beberapa jenis predominan lain dan memiliki urgensi, namun belum memiliki status konservasi yang jelas. Kukla et al., 2018 menyatakan tidak terdapat perbedaan kadar biomassa mikroba, $\mathrm{C}, \mathrm{N}$, dan $\mathrm{P}$ pada beberapa tahapan suksesi sekunder akibat pemberaan lahan di New Guinea, namun sistem tebas bakar pada hutan sekunder meningkatkan ketersediaan nutrisi di tanah. Sejalan dengan permasalahan saat ini yakni penurunan kesuburan tanah di lahan-lahan bera, namun laju pertambahan penduduk meningkat, mengakibatkan perladangan berpindah menjadi intens dan berdampak pada pendeknya sistem bera (Kartikasari et al., 2012). Berdasarkan survei awal, lahan bera yang telah berumur lebih dari 10 tahun umum dijumpai di Distrik Sidey Manokwari Papua Barat, sehingga vegetasi pohon di lahan bera menjadi dominan. Perlu dibuat sebuah catatan konservasi berdasarkan International Union for Conservation of Nature Resources (IUCN) di lahan bera Womnowi Sidey Manokwari, seperti penelitian terbaru oleh Amber et al., 2019 dan Yirdaw et al., 2019, khususnya pada vegetasi fase pohon. Tujuan penelitian ini adalah melakukan inventarisasi jenis di lahan bera 15 tahun Womnowi Sidey Manokwari yang tergolong dalam daftar IUCN, menggunakan pendekatan analisis vegetasi.

\section{Lokasi Penelitian}

\section{Bahan dan Metode}

Penelitian dilaksanakan pada minggu pertama bulan Mei 2018, di lahan bera berumur 15 tahun Womnowi Sidey Manokwari (S048'17.2"-S048'10,2" s.d E133²8'59,2"$\left.\mathrm{E} 133^{\circ} 28^{\prime} 53.62^{\prime \prime}\right)$. Saat penelitian tercatat suhu $28^{\circ} \mathrm{C}$, kelembaban (relative humidity) $75 \%$, dan ketinggian lokasi penelitian $132 \mathrm{mdpl}$.

\section{Alat}

Global positioning system (GPS), kompas, meter rol, buku lapangan (dengan tally sheet), tali tambang, dan parang. 


\section{Prosedur Penelitian}

\section{Analisis Vegetasi Fase Pohon}

Analisis vegetasi menggunakan metode continuous strip sampling (Gambar 1) yang merupakan modifikasi dari model garis berpetak (Lekitoo dan Khayati, 2019). Analisis vegetasi dilakukan pada total luas 1 ha (25 petak sampling), arah rintis sampling ditentukan secara visual berdasar pada kerapatan vegetasi. Fase pohon yang dicacah meliputi tiang (poles) dan pohon (trees) berdasarkan ukuran diameter batang (Hadiah et al., 2019; Yirdaw et al., 2019). Ukuran petak sampling pada fase tiang adalah $10 \times 10$ meter dengan diameter batang setinggi dada 10 sampai $<20 \mathrm{~cm}$, dan fase pohon memiliki ukuran petak sampling $20 \times 20 \mathrm{~m}$ diukur pada diameter batang setinggi dada lebih besar sama dengan $20 \mathrm{~cm}$ (Murdjoko et al., 2016). Alasan diikutsertakan fase tiang pada analisis vegetasi pohon adalah karena fase tiang memiliki kontribusi tutupan kanopi, sehingga aspek dominasinya perlu diperhatikan. Hadiah et al., 2019 menggolongkan tumbuhan berkayu yang memiliki diameter $\geq 10$ termasuk dalam kelompok pohon.

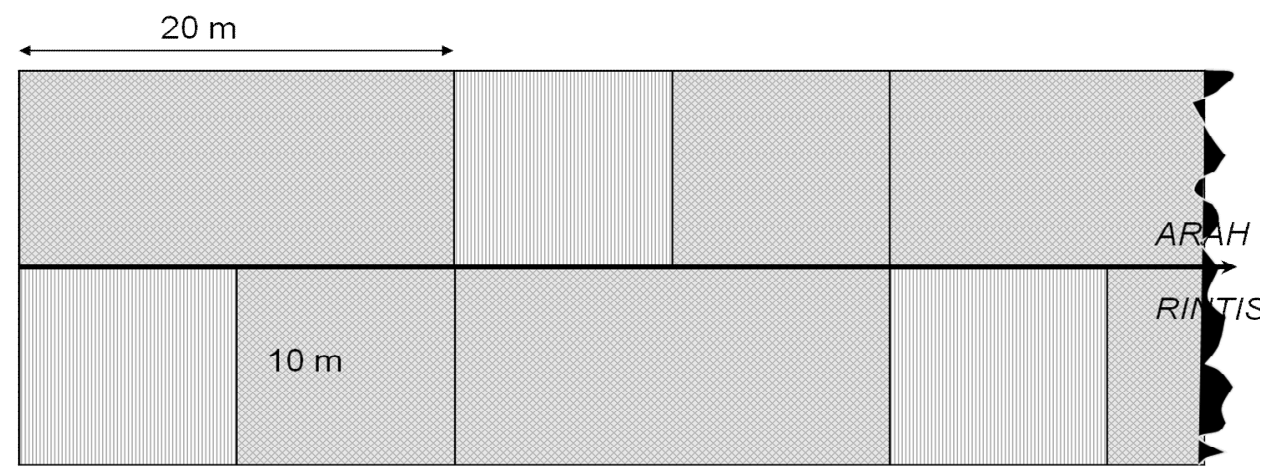

Gambar 1. Sketsa continuous strip sampling dalam analisis vegetasi di lahan bera Womnowi Sidey Manokwari

\section{Identifikasi Status Konservasi Berdasarkan Data IUCN}

Status konservasi jenis diakses secara online di website iucnredlist.org/search. Masing - masing jenis yang telah teridentifikasi melalui pencacahan di lapangan di enteri ke dalam website IUCN (IUCN, 2019). Selain itu setiap nama jenis disertakan authornya berdasarkan data IUCN yang terhubung dengan beberapa website catalogue of life seperti Kew herbarium, the plant list, dan CITES.

\section{Analisis Data}

Data diinterpretasikan menggunakan persamaan analisis vegetasi untuk menentukan nilai penting masing-masing jenis (Pereki et al., 2013; Yirdaw et al., 2019). Persamaan yang digunakan adalah :

INP=KR+FR+DR;

di mana INP adalah indeks nilai penting yang merupakan kumulatif dari kepadatan relatif, frekuensi relatif, dan dominasi relatif. Nilai KR, FR, dan DR diperoleh menggunakan persamaan berikut :

$$
\begin{aligned}
& \mathbf{K}=\frac{\text { jumlah individu zuaru jenis }}{\text { total luazarea zampling }} \\
& \mathbf{K R}=\frac{\text { jumlah individu auatu jenis }}{\text { total individu zeluruhjenis }} \times 100 \\
& \mathbf{F}=\frac{\text { jumlah subpetakditemukan suatu jemis }}{\text { jumlah seluruhpetak }} \\
& \mathbf{F R}=\frac{\text { frekuensi suatu jenis }}{\text { frekuensi seluruh jenis }} \times 100
\end{aligned}
$$


$\mathbf{D}=$ Basal Area $(\mathbf{G})=\frac{\text { luas bidang dazar suatu jenis }}{\text { luas petak }}$

Luas bidang dasar suatu jenis diukur dengan persamaan:

$\mathrm{LBD}=1 / 4 \pi \cdot \mathrm{D}^{2}$ atau $\mathrm{LBD}=\frac{\mathrm{GEH}}{4 \pi}$

dimana $D$ adalah diameter tumbuhan setinggi dada atau girth at breast height dalam satuan meter (Folega et al., 2011).

DR $=\frac{\text { dominasi suatu jenis }}{\text { dominasi seluruh jenis }} \times 100$

Data diproses dan diinterpretasikan menggunakan program Microsoft Office Excel 2007, selanjutnya INP jenis dan informasi terbaru mengenai jenis yang tergolong dalam kategori IUCN direpresentasikan dalam penelitian ini.

\section{Hasil}

Gambaran Umum Status Konservasi Vegetasi Pohon

Sebanyak 21 jenis dari total vegetasi pohon (tiang dan pohon) (Tabel 1) terkategori least concern (LC), near threatened (NT), dan vulnerable (V) menurut IUCN (2019). Total vegetasi pohon yang telah teridentifikasi di luas area sampling 1 ha adalah 65 jenis yang terdiri dari 378 individu, masing - masing 182 individu fase tiang dan 196 individu fase pohon. Rerata persentase jenis yang tergolong dalam daftar IUCN kurang dari $30 \%$, sedangkan rerata persentase individu jenis yang tergolong dalam daftar IUCN lebih dari 35\%.

Tabel 1. Daftar Vegetasi Pohon Dalam Status IUCN di Lahan Bera Womnowi Sidey Manokwari

\begin{tabular}{llllllll}
\hline No & Nama Jenis & $\mathbf{J l}^{*}$ & $\mathbf{J l}^{\wedge}$ & $\mathbf{T}$ & INP $^{\boldsymbol{*}}$ & INP^$^{\wedge}$ & SK \\
\hline $\mathbf{1}$ & Aglaia odorata Lour. & 2 & 0 & 2 & 3.49 & 0.00 & NT \\
$\mathbf{2}$ & Aglaia spectabilis (Miq.) Jain \& Bennet. & 1 & 0 & 1 & 1.81 & 0.00 & LC \\
$\mathbf{3}$ & Alstonia scholaris (L.) R. Br. & 1 & 4 & 5 & 1.67 & 6.11 & LC \\
$\mathbf{4}$ & Calophyllum soulattri Burm. f. & 2 & 0 & 2 & 3.21 & 0.00 & LC \\
$\mathbf{5}$ & Canarium hirsutum Willd. & 2 & 1 & 3 & 4.26 & 1.50 & LC \\
$\mathbf{6}$ & Gnetum gnemon L. & 1 & 0 & 1 & 1.60 & 0.00 & LC \\
$\mathbf{7}$ & Homalium foetidum (Roxb.) Benth. & 2 & 3 & 5 & 3.64 & 4.80 & LC \\
$\mathbf{8}$ & Horsfieldia irya (Gaertn.) Warb. & 1 & 0 & 1 & 1.60 & 0.00 & LC \\
$\mathbf{9}$ & Horsfieldia laevigata Warb. & 1 & 0 & 1 & 1.89 & 0.00 & LC \\
$\mathbf{1 0}$ & Intsia bijuga (Colebr.) Kuntze. & 1 & 0 & 1 & 1.81 & 0.00 & V \\
$\mathbf{1 1}$ & Lepiniopsis ternatensis Valeton. & 1 & 0 & 1 & 1.74 & 0.00 & LC \\
$\mathbf{1 2}$ & Litsea timoriana Span. & 3 & 4 & 7 & 6.02 & 5.98 & LC \\
$\mathbf{1 3}$ & Mangifera minor Blume. & 0 & 3 & 3 & 0.00 & 4.29 & LC \\
$\mathbf{1 4}$ & Maasia sumatrana (Miq.) et Mols. & 1 & 0 & 1 & 1.67 & 0.00 & LC \\
$\mathbf{1 5}$ & Melicope elleryana (F. Muell.) T.G. Hartley. & 2 & 0 & 2 & 3.55 & 0.00 & LC \\
$\mathbf{1 6}$ & Medusanthera laxiflora (Miers.) R. A. Howard. & 1 & 0 & 1 & 1.74 & 0.00 & LC \\
$\mathbf{1 7}$ & Octomeles sumatrana Miq. & 6 & 16 & 22 & 10.19 & 36.51 & LC \\
$\mathbf{1 8}$ & Polyscias nodosa (Blume.) Seem. & 1 & 0 & 1 & 1.98 & 0.00 & LC \\
\hline
\end{tabular}




\begin{tabular}{llllllll}
\hline $\mathbf{1 9}$ & Sterculia shillinglawii F.Muell. & 3 & 0 & 3 & 6.12 & 0.00 & LC \\
$\mathbf{2 0}$ & Teijsmanniodendron bogoriense Koord. & 1 & 0 & 1 & 1.81 & 0.00 & LC \\
$\mathbf{2 1}$ & Tetrameles nudiflora R. Br. & 8 & 16 & 24 & 16.27 & 24.34 & LC \\
& Total & 41 & 47 & 88 & 76.05 & 83.53 & \\
\hline
\end{tabular}

Jl=jumlah individu; T=total; *INP fase tiang; ^INP fase pohon; SK=status konservasi

Status LC mendominasi jenis-jenis vegetasi pohon, khususnya pada fase tiang (Tabel 1), dibanding status NT dan V. Lebih dari $90 \%$ jenis dan individu vegetasi pohon yang tergolong dalam daftar IUCN di lahan bera Womnowi Sidey Manokwari berstatus LC. Dari total INP vegetasi tiang dan pohon (600\%), 159.58\% merupakan INP dari jenis yang tergolong dalam daftar IUCN (Tabel 1). Meskipun vegetasi fase pohon hanya memiliki sedikit jenis yang tergolong dalam daftar IUCN, namun memiliki nilai penting yang lebih tinggi dibanding fase tiang (Tabel 1), hal ini disebabkan oleh tingginya nilai dominasi relatif (DR) dan kepadatan relatif (KR) dari jenis-jenis yang tergolong dalam daftar IUCN (Tabel 2). Dua jenis yang menjadi sorotan utama adalah T. nudiflora dan O. sumatrana, kedua jenis dari famili Tetramelaceae ini tergolong dalam lima INP tertinggi fase pohon dan berstatus LC.

Tabel 2. Hasil Analisis Vegetasi Pohon di Lahan Bera Womnowi Sidey Manokwari

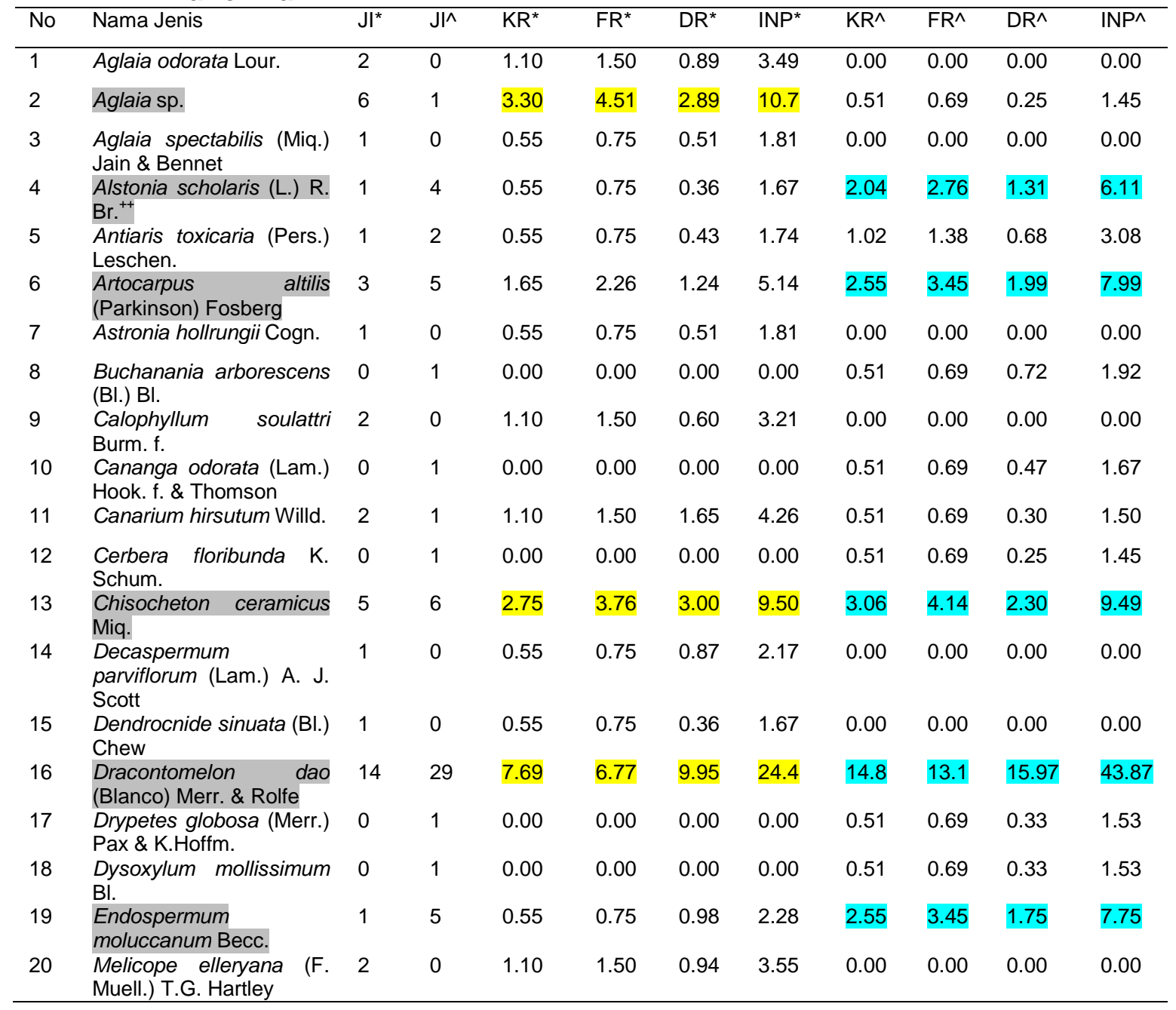


BIOMA : JURNAL BIOLOGI MAKASSAR, 4(2) : 107-120, JULI-DES 2019

\begin{tabular}{|c|c|c|c|c|c|c|c|c|c|c|c|}
\hline 21 & $\begin{array}{l}\text { Ficus nodosa Teijsm. \& } \\
\text { Binn. }\end{array}$ & 1 & 1 & 0.55 & 0.75 & 0.36 & 1.67 & 0.51 & 0.69 & 0.25 & 1.45 \\
\hline 22 & $\begin{array}{l}\text { Ficus pungens Reinw. ex } \\
\text { Blume. }\end{array}$ & 1 & 0 & 0.55 & 0.75 & 0.36 & 1.67 & 0.00 & 0.00 & 0.00 & 0.00 \\
\hline 23 & $\begin{array}{l}\text { Ficus trachypison K. } \\
\text { Schum. ex K. Schum. \& } \\
\text { Lauterb. }\end{array}$ & 1 & 0 & 0.55 & 0.75 & 0.36 & 1.67 & 0.00 & 0.00 & 0.00 & 0.00 \\
\hline 24 & Garcinia latissima Miq. & 1 & 0 & 0.55 & 0.75 & 0.51 & 1.81 & 0.00 & 0.00 & 0.00 & 0.00 \\
\hline 25 & $\begin{array}{l}\text { Gmelina arborea Roxb. } \\
\text { ex Sm. }\end{array}$ & 1 & 0 & 0.55 & 0.75 & 0.30 & 1.60 & 0.00 & 0.00 & 0.00 & 0.00 \\
\hline 26 & Gnetum gnemon L. & 1 & 0 & 0.55 & 0.75 & 0.30 & 1.60 & 0.00 & 0.00 & 0.00 & 0.00 \\
\hline 27 & Gomphandra globosa & 0 & 1 & 0.00 & 0.00 & 0.00 & 0.00 & 0.51 & 0.69 & 0.21 & 1.41 \\
\hline 28 & Goniothalamus sp. & 0 & 1 & 0.00 & 0.00 & 0.00 & 0.00 & 0.51 & 0.69 & 0.21 & 1.41 \\
\hline 29 & $\begin{array}{l}\text { Gonocaryum litorale } \\
\text { (Blume) Sleumer. }\end{array}$ & 6 & 3 & 3.30 & 4.51 & 3.77 & 11.6 & 1.53 & 2.07 & 1.75 & 5.35 \\
\hline 30 & $\begin{array}{l}\text { Homalium foetidum } \\
\text { (Roxb.) Benth. }\end{array}$ & 2 & 3 & 1.10 & 1.50 & 1.04 & 3.64 & 1.53 & 2.07 & 1.20 & 4.80 \\
\hline 31 & $\begin{array}{l}\text { Horsfieldia irya (Gaertn.) } \\
\text { Warb. }\end{array}$ & 1 & 0 & 0.55 & 0.75 & 0.30 & 1.60 & 0.00 & 0.00 & 0.00 & 0.00 \\
\hline 32 & Horsfieldia laevigata & 1 & 0 & 0.55 & 0.75 & 0.59 & 1.89 & 0.00 & 0.00 & 0.00 & 0.00 \\
\hline 33 & $\begin{array}{l}\text { Intsia bijuga (Colebr.) } \\
\text { Kuntze }\end{array}$ & 1 & 0 & 0.55 & 0.75 & 0.51 & 1.81 & 0.00 & 0.00 & 0.00 & 0.00 \\
\hline 34 & $\begin{array}{l}\text { Kokoona ochracea } \\
\text { (Elmer) Merr. }\end{array}$ & 1 & 0 & 0.55 & 0.75 & 0.30 & 1.60 & 0.00 & 0.00 & 0.00 & 0.00 \\
\hline 35 & $\begin{array}{l}\text { Koordersiodendron } \\
\text { pinnatum (Blanco) Merr. }\end{array}$ & 0 & 1 & 0.00 & 0.00 & 0.00 & 0.00 & 0.51 & 0.69 & 0.28 & 1.48 \\
\hline 36 & $\begin{array}{l}\text { Lansium domesticum } \\
\text { Correa. }\end{array}$ & 62 & 27 & 34.07 & 17.3 & 31.9 & 83.3 & 13.8 & 11.0 & 8.25 & 33.1 \\
\hline 37 & $\begin{array}{l}\text { Lepiniopsis ternatensis } \\
\text { Valeton. }\end{array}$ & 1 & 0 & 0.55 & 0.75 & 0.43 & 1.74 & 0.00 & 0.00 & 0.00 & 0.00 \\
\hline 38 & Litsea ledermanii Tesch. & 0 & 2 & 0.00 & 0.00 & 0.00 & 0.00 & 1.02 & 1.38 & 0.42 & 2.82 \\
\hline 39 & Litsea timoriana Span. $^{++}$ & 3 & 4 & 1.65 & 2.26 & 2.11 & 6.02 & 2.04 & 2.76 & 1.18 & 5.98 \\
\hline 40 & $\begin{array}{l}\text { Macaranga mappa (L.) } \\
\text { Müll.Arg. }\end{array}$ & 1 & 0 & 0.55 & 0.75 & 0.36 & 1.67 & 0.00 & 0.00 & 0.00 & 0.00 \\
\hline 41 & Mangifera minor Blume. & 0 & 3 & 0.00 & 0.00 & 0.00 & 0.00 & 1.53 & 2.07 & 0.69 & 4.29 \\
\hline 42 & $\begin{array}{l}\text { Maniltoa browneoides } \\
\text { Harms. }\end{array}$ & 1 & 0 & 0.55 & 0.75 & 0.51 & 1.81 & 0.00 & 0.00 & 0.00 & 0.00 \\
\hline 43 & $\begin{array}{l}\text { Medusanthera laxiflora } \\
\text { (Miers) R. A. Howard }\end{array}$ & 1 & 0 & 0.55 & 0.75 & 0.43 & 1.74 & 0.00 & 0.00 & 0.00 & 0.00 \\
\hline 44 & $\begin{array}{l}\text { Melanolepis } \\
\text { multiglandulosa (Reinw. } \\
\text { ex Blume) Rchb. \& Zoll. }\end{array}$ & 2 & 3 & 1.10 & 1.50 & 1.45 & 4.05 & 1.53 & 2.07 & 1.34 & 4.94 \\
\hline 45 & Melicope sp. & 0 & 1 & 0.00 & 0.00 & 0.00 & 0.00 & 0.51 & 0.69 & 0.41 & 1.61 \\
\hline 46 & Milliusa sp. & 1 & 0 & 0.55 & 0.75 & 0.30 & 1.60 & 0.00 & 0.00 & 0.00 & 0.00 \\
\hline 47 & $\begin{array}{l}\text { Octomeles sumatrana } \\
\text { Miq. }^{++}\end{array}$ & 6 & 16 & 3.30 & 3.76 & 3.14 & 10.2 & 8.16 & 8.97 & 19.38 & 36.51 \\
\hline 48 & $\begin{array}{l}\text { Palaquium lobbianum } \\
\text { Burck. }\end{array}$ & 1 & 2 & 0.55 & 0.75 & 0.36 & 1.67 & 1.02 & 1.38 & 0.71 & 3.11 \\
\hline 49 & $\begin{array}{l}\text { Parartocarpus venenosa } \\
\text { (Zoll. \& Mor.) Becc. }\end{array}$ & 2 & 2 & 1.10 & 1.50 & 1.64 & 4.24 & 1.02 & 1.38 & 0.83 & 3.23 \\
\hline 50 & Picrasma javanica & 0 & 1 & 0.00 & 0.00 & 0.00 & 0.00 & 0.51 & 0.69 & 0.23 & 1.43 \\
\hline 51 & $\begin{array}{l}\text { Pimelodendron } \\
\text { amboinicum Hassk. }\end{array}$ & 3 & 8 & 1.65 & 2.26 & 1.31 & 5.21 & 4.08 & 4.14 & 3.93 & 12.15 \\
\hline 52 & Pisonia grandis R. Br. & 3 & 0 & 1.65 & 2.26 & 0.97 & 4.87 & 0.00 & 0.00 & 0.00 & 0.00 \\
\hline 53 & $\begin{array}{l}\text { Maasia sumatrana (Miq.) } \\
\text { et Mols. }\end{array}$ & 1 & 0 & 0.55 & 0.75 & 0.36 & 1.67 & 0.00 & 0.00 & 0.00 & 0.00 \\
\hline 54 & $\begin{array}{l}\text { Polyscias nodosa } \\
\text { (Blume.) Seem. }\end{array}$ & 1 & 0 & 0.55 & 0.75 & 0.68 & 1.98 & 0.00 & 0.00 & 0.00 & 0.00 \\
\hline 55 & $\begin{array}{l}\text { Pometia pinnata Forst. \& } \\
\text { Forst. }\end{array}$ & 15 & 35 & 8.24 & 8.27 & 9.51 & 26.0 & 17.9 & 11.7 & 19.4 & 48.98 \\
\hline 56 & $\begin{array}{l}\text { Prainea limpato (Miq.) } \\
\text { Beumee. ex K. Heyne. }\end{array}$ & 1 & 0 & 0.55 & 0.75 & 0.30 & 1.60 & 0.00 & 0.00 & 0.00 & 0.00 \\
\hline 57 & $\begin{array}{l}\text { Pterygota horsfieldii } \\
\text { (R.Br.) Kosterm. }\end{array}$ & 0 & 2 & 0.00 & 0.00 & 0.00 & 0.00 & 1.02 & 1.38 & 0.68 & 3.08 \\
\hline
\end{tabular}




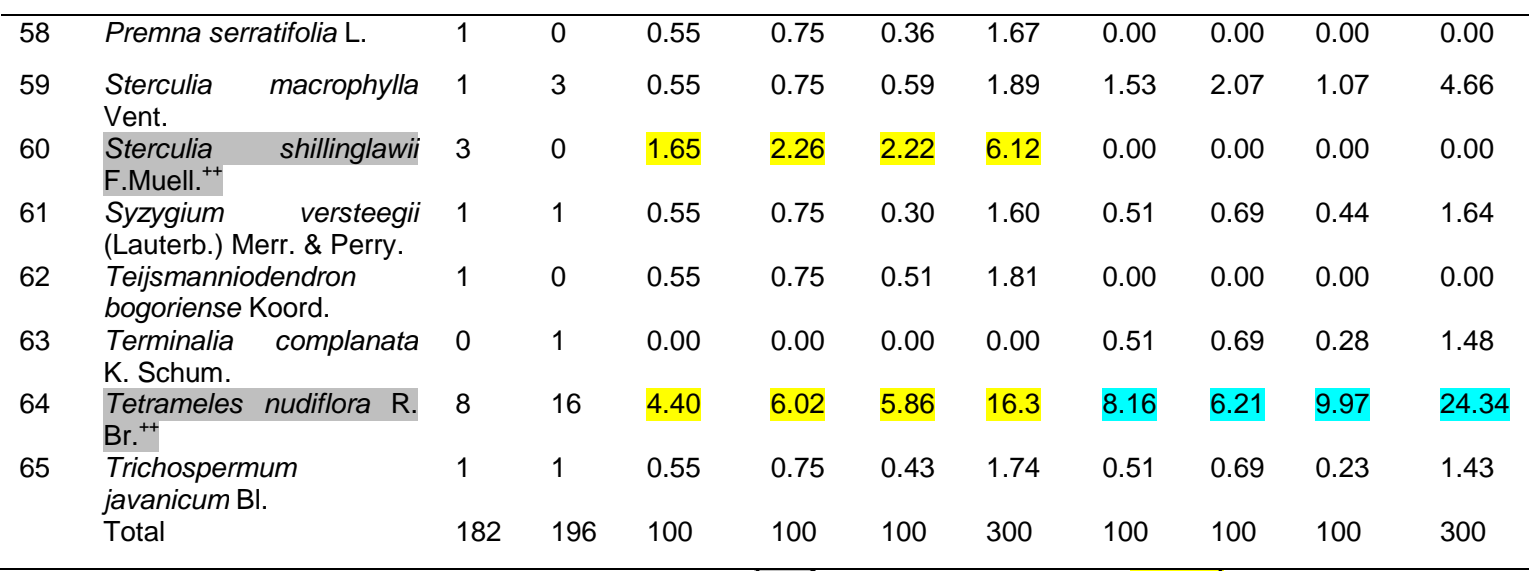

Keterangan: *fase tiang; ^^ase pohon; ${ }^{\text {huruf }}=$ INP tertinggi; ${ }^{\text {numeral }}=$ sepuluh INP tertinggi fase tiang; ${ }^{\text {numeral }}=$ sepuluh INP tertinggi fase pohon (Susanto et al., 2018); ${ }^{++}=$terkategori IUCN (2019)

Terdapat empat jenis termasuk ke dalam sepuluh INP tertinggi dan terkategori dalam daftar IUCN pada fase tiang dan/atau pohon, yaitu : T. nudiflora, O. sumatrana, S. shillinglawii, dan L. timoriana (Tabel 1 dan 2). Keempat jenis tersebut berstatus LC berdasarkan IUCN (2019). Selain jenis yang dominan, kehadiran fase tiang dari I. bijuga (status V) dan A. odorata (status NT) menambah nilai penting status konservasi jenis di lahan bera Womnowi Sidey Manokwari.

Status Konservasi Vegetasi Pohon: Fase Tiang

Dari total 51 jenis vegetasi fase tiang, 20 jenis (39\%) di antaranya berstatus LC, NT, dan V. Jumlah individu menunjukkan lebih dari 50\% tidak terkategori dalam daftar IUCN (2019). Status konservasi LC lebih mendominasi dibanding NT dan V. Gambar 1 menunjukkan status konservasi jenis pada fase tiang.

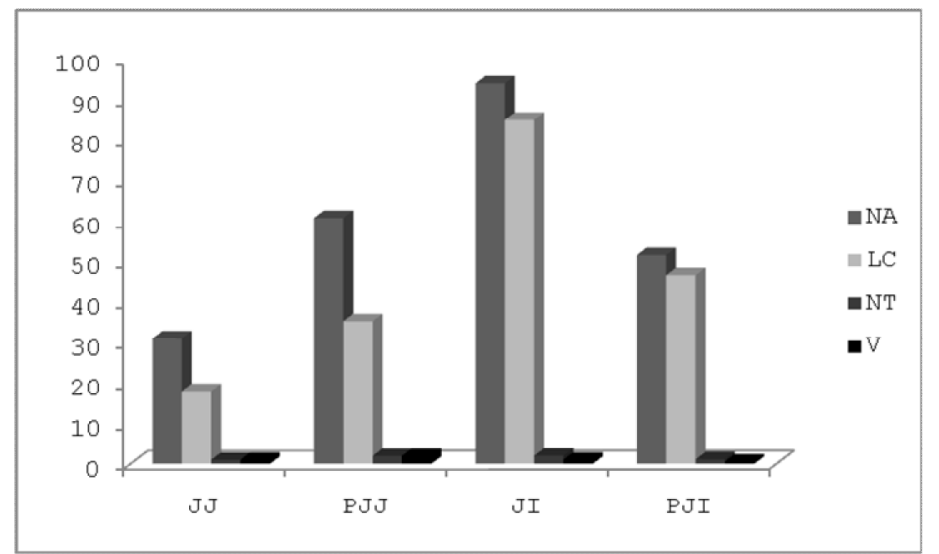

Gambar 1. Persentase Jenis dan Individu Fase Tiang Yang Terkategori Dalam lucn Di Lahan Bera Womnowi Sidey Manokwari

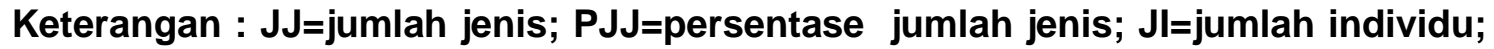
PJI=persentase jumlah individu; NA=tidak/belum terkategori dalam IUCN; LC=kurang diperhatikan; NT=dekat keterancaman; V=rentan

Status Konservasi Vegetasi Pohon : Fase Pohon

Jumlah jenis pada fase pohon yang tergolong dalam daftar IUCN lebih sedikit dibanding jumlah individu (Gambar 3). Sebanyak 196 individu yang terdiri dari 37 jenis fase pohon hanya tujuh jenis yang terdiri dari 47 individu yang tergolong dalam daftar 
IUCN. Lebih dari $80 \%$ jenis fase pohon tidak terkategori dalam daftar IUCN, namun yang terkategori dalam daftar IUCN semuanya berstatus LC.

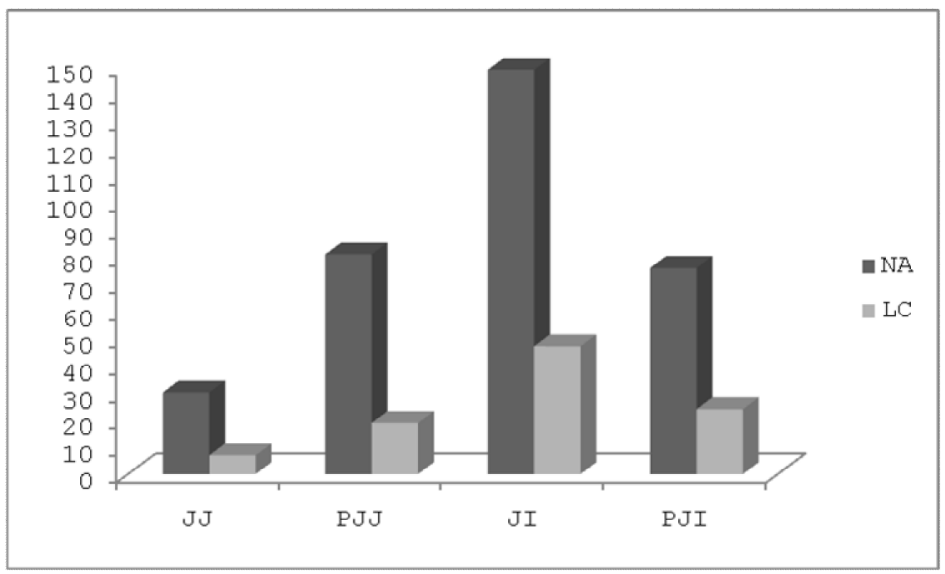

\section{Gambar 1. Persentase Jenis dan Individu Fase Pohon Yang Terkategori Dalam IUCN Di Lahan Bera 15 Tahun Womnowi Sidey Manokwari}

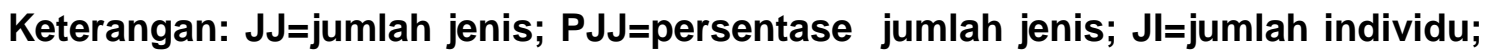
PJI=persentase jumlah individu; NA=tidak/belum terkategori dalam IUCN; LC=kurang diperhatikan

\section{Pembahasan}

Vegetasi pohon di lahan bera 15 tahun Womnowi Sidey Manokwari tidak hanya memiliki potensi untuk merubah iklim mikro di lahan bera (Susanto et al., 2019), namun memiliki nilai penting konservasi cukup tinggi. Pada luas area sampling yang relatif sempit (1 ha) ditemukan jenis - jenis tergolong dalam status LC, NT, dan V (Tabel 1). Jenis pohon dominan yang melingkupi lahan bera berumur 15 tahun Womnowi Sidey Manokwari adalah P. pinnata, D. dao, O. sumatrana, dan T. nudiflora. Kehadiran dua jenis dari famili Tetramelaceae (O. sumatrana, dan T. nudiflora) merupakan indikasi tanah alluvial (Susanto et al., 2018). Kehadiran jenis L. domesticum pada lahan bera berumur 15 tahun mengindikasikan sistem bera diperkaya sebagai model agroforestri. Folega et al., 2011 menyatakan di lahan bera berbatasan dengan area terlindungi Togo Afrika ditemukan empat jenis vegetasi agroforestri yang memiliki potensi umum sebagai bahan makanan. Hasil ini menunjukkan hal yang sewajarnya jika masyarakat lokal di Papua Barat menggunakan model agroforestri di lahan bera.

Jumlah jenis yang tergolong dalam daftar IUCN pada fase tiang lebih banyak dibanding fase pohon, namun jumlah individu yang tergolong dalam daftar IUCN lebih banyak pada fase pohon (Tabel 1). Daya regenarasi vegetasi pohon cukup unik, dimana jumlah individu fase pohon lebih banyak dibanding fase tiang (Gambar 1 dan 2). Secara gradual jenis pada fase pohon memiliki nilai penting yang lebih tinggi dibanding fase tiang, walaupun tiang memiliki jumlah jenis yang lebih banyak. Amber et al., 2019 menyatakan komposisi jenis dipengaruhi oleh aktivitas manusia, faktor tanah, dan efek iklim regional. Ketiga faktor tersebut terungkap dalam penelitian ini, dimana aktivitas manusia khususnya penanaman menghasilkan model jenis vegetasi bera diperkaya seperti kehadiran L. domesticum. Efek dominasi L. domesticum berdampak pada nilai dominasi dan keragaman jenis lainnya (Susanto et al., 2018), sehingga turut berpengaruh pada jenis yang terkategori dalam IUCN. Faktor tanah mengindikasikan kelompok vegetasi yang berada di daerah tanah endapan (alluvial), ditemukan jenis 
vegetasi pohon dominan seperti $P$. pinnata, $D$. dao, $O$. sumatrana, T. nudiflora, dan A. Altilis (Paijmans, 1976). Jenis indikan tanah alluvial (O. sumatrana, T. nudiflora) termasuk dalam daftar IUCN. Efek iklim regional menunjukkan di dataran rendah Papua Barat memiliki vegetasi yang hampir mirip, Lekitoo dan Khayati (2019) menunjukkan vegetasi kawasan hutan lindung KPHL Sorong Papua Barat (Kabupaten berbeda dari lokasi penelitian ini), menunjukkan vegetasi didominasi oleh Vaticca rassak, P. pinnata dan P. amboinicum, H. foetidum, P. lobbanium. Jenis dominan yang ditemukan dalam penelitian tersebut semua hadir dalam penelitian ini, kecuali V. rassak. Hadirnya jenis $P$. pinnata di strata teratas merupakan ciri khas dari hutan dataran rendah di Papua (Paijmans, 1976), namun hingga saat ini jenis tersebut belum termasuk dalam kategori IUCN.

Dua jenis (A. odorata dan I. bijuga) tergolong dalam status NT dan V merupakan ciri khas dari vegetasi yang hadir pada dataran rendah di Papua (Paijmans, 1976), A. odorata (NT) umum tumbuh di hutan sekunder (Pannell, 1998), namun merupakan wild in nature bukan sengaja ditanam oleh masyarakat lokal. Jenis I. bijuga merupakan kayu komersil yang dijuluki sebagai 'kayu besi' merupakan ciri khas dataran rendah hutan tropis (WCMC, 1998), jenis tersebut lebih umum ditemukan di daerah dataran rendah yang berupa rawa dibanding pada daerah aliran sungai (Paijmans, 1976). Pada area sampling di Womnowi Sidey Manokwari merupakan daerah yang di apit oleh dua sungai yakni Sungai Kasi dan Sungai Womnowi, sehingga diduga inventarisasi dilakukan di lahan bera bertanah endapan, sehingga jenis I. Bijuga kurang mendominasi, bahkan tidak muncul di fase pohon (Tabel 1). Jika diperhatikan, 'assessment IUCN' menurut Pannell (1998) dan WCMC (1998) telah lebih dari 20 tahun, sehingga rendahnya KR dan FR (Tabel 2) kedua jenis ini menjadi gambaran untuk dilakukannya 'assessment' kembali.

Beberapa jenis yang tergolong LC pada dasarnya merupakan jenis-jenis asli di Papua. Menurut IUCN (2019) jenis dengan kategori LC merupakan jenis berstatus kurang diperhatikan atau memiliki resiko rendah terhadap kepunahan, namun berdasarkan rekam jejak penelitian terbaru (Tabel 3), beberapa jenis yang tergolong LC memiliki prospek dalam segi ekologi dan medis. Jenis yang tergolong LC barangkali menjadi prospek dan tantangan mengenai pemanfaatannya, khususnya jika jenis yang tergolong LC bukan merupakan jenis dominan.

Tabel 3. Rekam Jejak Penelitian Terbaru Mengenai Jenis Vegetasi Pohon Yang Tergolong Dalam Kategori LC IUCN di Lahan Bera Womnowi Sidey Manokwari

\begin{tabular}{|c|c|c|c|}
\hline No & Nama & $\begin{array}{l}\text { Tahun } \\
\text { assessme } \\
\text {-nt IUCN }\end{array}$ & Rekam jejak penelitian \\
\hline 1 & $\begin{array}{ll}\text { Aglaia } & \text { spectabilis } \\
\text { (Miq.) Jain \& } \\
\text { Bennet. }\end{array}$ & 2018 & $\begin{array}{l}\text { Termasuk dalam jenis dominan dan memiliki dua } \\
\text { kategori konservasi di Barat Laut Vietnam (Hoa } \\
\text { Hong Dao dan Hölscher, 2015); hadir dengan INP } \\
\text { rendah pada kelompok ekologi dan asosiasi } \\
\text { dengan I. bijuga dan Pometia (Murdjoko et al., } \\
\text { 2016; Sirami et al., 2019) }\end{array}$ \\
\hline 2 & $\begin{array}{l}\text { Alstonia scholaris } \\
\text { (L.) R. Br. }\end{array}$ & 1998 & $\begin{array}{l}\text { Ekstrak daun A. scholaris memiliki daya } \\
\text { antibakteri, sehingga berpotensi dikembangkan di } \\
\text { bidang farmasi dan industri (Hussein dan Jamal, } \\
\text { 2019); dominan di lahan bera Bremi Manokwari } \\
\text { Utara (Budirianto dan Ratnawati, 2018) }\end{array}$ \\
\hline 3 & $\begin{array}{l}\text { Calophyllum } \\
\text { soulattri Burm. f. }\end{array}$ & 1998 & $\begin{array}{l}\text { Kadar methanol dari ekstrak daun, kulit kayu, dan } \\
\text { akar memiliki daya antimikroba, khususnya pada }\end{array}$ \\
\hline
\end{tabular}


Canarium hirsutum 2018 Willd.

$5 \quad$ Gnetum gnemon L. 2013

6

Maasia sumatrana 2018 (Miq.) et Mols.

$7 \quad$ Melicope elleryana 2018 (F. Muell.) T.G. Hartley.

Homalium foetidum 1998 (Roxb.) Benth.

$9 \quad$ Horsfieldia irya 1998 (Gaertn.) Warb.

10 Horsfieldia 2019 laevigata Warb.

11 Lepiniopsis ternatensis Valeton.

12 Litsea timoriana 2018 Span.

13 Mangifera minor 2016 Blume. bagian akar (Khan et al., 2002); memiliki jenis senyawa phloroglucinol yang baru bernama calosubellinone dan garsubellin B sebagai agen penghambat sel kanker (sel HeLa) (Lim et al., 2017)

Ditemukan di Pulau Numfor Papua sebagai vegetasi tiga besar INP, yang merupakan habitat kuskus (Sinery et al., 2016); memiliki asosiasi positif dengan $\mathrm{P}$. acuminata di unlogged forest Selatan Papua (Murdjoko et al., 2016); dominan di dataran tinggi lahan bera Bremi Manokwari Utara (Budirianto dan Ratnawati, 2018)

Telah diujikan pada mencit bahwa biji G. gnemon memiliki senyawa antitumor (Narayanan et al., 2015); daun muda dan bijinya sebagai pakan kuskus (Handayani dan Kunda, 2019)

Hadir sebagai jenis pohon yang berasosiasi dengan Pometia di area penebangan di Selatan Papua (Murdjoko et al., 2016)

Memiliki kandungan caryophylene, bicyclogermacrene, zierone, dan evodone sebagai zat untuk mengurangi lemak berlebih pada tubuh (Hwang et al., 2016); memiliki asosiasi positif dengan P. pinnata di area penebangan di Selatan Papua (Murdjoko et al., 2016)

Ditemukan sebagai jenis dominan di lahan bera dataran rendah Bremi Manokwari Utara (Budirianto dan Ratnawati, 2018); Wu et al., (2018) menyatakan genus Homalium memiliki dihydrochalcone glycosidase dan flavonoid sebagai agen antibakteri

Sebagai naungan alternatif dan komplemen dari jenis

I. bijuga dan memiliki manfaaat sebagai racun ikan (Sirami et al., 2019); termasuk INP tertinggi fase tiang di lahan bera Bremi Manokwari Utara (Budirianto dan Ratnawati, 2018)

Sebagai naungan alternatif dan komplemen dari jenis

I. bijuga dan memiliki manfaaat sebagai racun ikan (Sirami et al., 2019); merupakan jenis dengan INP tertinggi fase pohon di habitat kuskus di Pulau Numfor Papua (Sinery et al., 2016)

Termasuk tiga jenis dominan fase pancang di habitat kuskus di Pulau Numfor Papua (Sinery et al., 2016)

Termasuk dalam jenis dominan di lahan bera dataran tinggi Bremi Manokwari Utara (Budirianto dan Ratnawati, 2018)

Hadir dengan INP rendah pada kelompok ekologi vegetasi dengan I. bijuga (Sirami et al., 2019); Genus Mangifera memiliki senyawa yang 


\begin{tabular}{|c|c|c|c|}
\hline & & & $\begin{array}{l}\text { berpotensi sebagai agen antimikroba (Doughari } \\
\text { dan Manzara, 2008) }\end{array}$ \\
\hline 14 & $\begin{array}{l}\text { Medusanthera } \\
\text { laxiflora (Miers) R. } \\
\text { A. Howard. }\end{array}$ & 2019 & $\begin{array}{l}\text { Buah M. laxiflora direbus dan dimasak oleh } \\
\text { masyarakat Suku Meyah Manokwari Utara } \\
\text { sebagai bahan makanan (Fatem et al., 2014); di } \\
\text { lahan bera Womnowi Sidey Manokwari M. } \\
\text { laxiflora termasuk dalam sepuluh INP tertinggi } \\
\text { fase semai dan pancang (Susanto et al., 2018) }\end{array}$ \\
\hline 15 & $\begin{array}{l}\text { Octomeles } \\
\text { sumatrana Miq. }\end{array}$ & 1998 & $\begin{array}{l}\text { Ditemukan di Kalimantan Timur, namun sebelum } \\
\text { proses penambangan batu bara (Komara et al., } \\
2016 \text { ); batang muda O. sumatrana digunakan } \\
\text { sebagai obat sakit gigi dengan cara dikunyah di } \\
\text { daerah Barangay Baganihan Davao City Filipina } \\
\text { (Guevara dan Garcia, 2018) }\end{array}$ \\
\hline 16 & $\begin{array}{l}\text { Polyscias nodosa } \\
\text { (Blume.) Seem. }\end{array}$ & 2018 & $\begin{array}{l}\text { Daun P. nodosa memiliki kandungan squalene, } \\
\text { phytyl fatty acid esters, lutein, } \beta \text {-sitosteryl-3ß- } \\
\text { glucopyranoside-6'-O-palmitate, stigmasterol, } \beta \text { - } \\
\text { sitosterol (Consolacion et al., 2015), yang memiliki } \\
\text { potensi antikanker dan antioksidan }\end{array}$ \\
\hline 17 & $\begin{array}{l}\text { Sterculia } \\
\text { shillinglawii } \\
\text { F.Muell. }\end{array}$ & 2018 & $\begin{array}{l}\text { BGCI IUCN (2018) menyatakan jenis S. } \\
\text { shillinglawii memiliki distribusi yang luas } \\
\text { khususnya di daerah New Guinea; biji dari genus } \\
\text { Sterculia memiliki potensi sebagai biodiesel (Ong } \\
\text { et al., 2013) }\end{array}$ \\
\hline 18 & $\begin{array}{l}\text { Teijsmanniodendro } \\
n \quad \text { bogoriense } \\
\text { Koord. }\end{array}$ & 2018 & $\begin{array}{l}\text { Ditemukan sebagai jenis dominan di lahan bera } \\
\text { Bremi Manokwari Utara (Budirianto dan } \\
\text { Ratnawati, 2018); ditemukan di daerah Tambraw } \\
\text { Papua Barat sebagai jenis predominan } \\
\text { (Robiansyah, 2018) }\end{array}$ \\
\hline 19 & $\begin{array}{l}\text { Tetrameles } \\
\text { nudiflora } \mathrm{R} . \mathrm{Br} \text {. }\end{array}$ & 1998 & $\begin{array}{l}\text { Kulit dari batang T. nudiflora memiliki kandungan } \\
\text { stigmasterol dan 20-epibryonolic acid yang } \\
\text { berpotensi sebagai antikanker, antidiabetes, dan } \\
\text { antioksidan (Minarti et al., 2018) }\end{array}$ \\
\hline
\end{tabular}

\section{Kesimpulan}

Jenis vegetasi pohon yang terkategori dalam IUCN di lahan bera Womnowi Sidey Manokwari tergolong cukup tinggi dalam area sampling 1 ha ditemukan 21 jenis terdiri dari 88 individu fase tiang dan pohon termasuk dalam daftar IUCN. Hanya terdapat tiga status konservasi yakni LC, NT, dan V, dimana jenis yang terkategori tersebut memiliki potensi yang amat penting. Total nilai penting jenis dalam kategori IUCN lebih tinggi fase pohon dibanding fase tiang, sebagai akibat dari tingginya jumlah individu dan nilai dominasi relatif. Lahan bera adalah bentuk hutan suksesi yang pasti akan digunakan kembali sebagai kebuh di masa mendatang, sehingga penelitian inventarisasi, analisis vegetasi, dan pendataan komposisi jenis di lahan bera dipandang perlu mencantumkan seluruh jenis yang didapat serta status konservasi berdasarkan IUCN. 


\section{Ucapan Terima Kasih}

Terima kasih kepada H.J. Budirianto, M.Si dan A.C. Maturbongs, M.Sc atas saransaran yang diberikan, Krisma Lekitoo, M.Sc sebagai pengenal jenis saat analisis vegetasi di lapangan, serta Bpk. Martinus Matabua sebagai pemilik lahan bera.

\section{Daftar Pustaka}

Allen, B.J., Hide, R.L., Bourke, R.M., Akus, W., Fritsch, D., Grau, R., Ling, G. and Lowes, E. 2002. Western Province: Text Summaries, Maps, Code Lists and Village Identification. Agricultural Systems of Papua New Guinea Working Paper No. 4. Land Management Group, Department of Human Geography, Research School of Pacific and Asian Studies, The Australian National University, Canberra. Revised edition.

Amber, K., Khan, K. R., Shah, A. H., Farooq, M., Lodhi, M. H., \& Shah, G. M. 2019. A comprehensive survey of floristic diversity evaluating the role of institutional gardening in conservation of plant biodiversity. International Journal of Biosciences, 14(3): 325-339.

[BGCI IUCN] Botanic Gardens Conservation International, IUCN SSC Global Tree Specialist Group. 2018. Sterculia shillinglawii. The IUCN Red List of Threatened Species 2018:

e.T135889531A135889538.

http://dx.doi.org/10.2305/IUCN.UK.20182.RLTS.T135889531A135889538.en. [diunduh 17 April 2019].

Budirianto, H.J. 2011. Hubungan model arsitekstur pohon Roux jenis Koordersiodendron pinnatum Merr. dan Koriba jenis Pometia pinata Forster terhadap parameter perimbangan air di hutan tanaman Anggori Manokwari.[Tesis]. Bogor (ID): Institut Pertanian Bogor.

Budirianto, H. J., \& Ratnawati, S. 2018. Struktur vegetasi lahan bera Kampung Bremi Pantai Utara Kabupaten Manokwari. In Prosiding Seminar Nasional MIPA UNIPA (Vol. 3, pp. 115-126).

Consolacion, R., Ebajo Jr, V., De Los Reyes, M., Brkljaca, R., \& Urban, S. 2015. Chemical constituents of Polyscias nodosa. Research Journal of Pharmaceutical, Biological and Chemical Sciences, 6(5): 1210-1214.

Doughari, J.H \& Manzara, S. 2008. In vitro antibacterial activity of crude leaf ectracts of Mangifera indica Linn. Afr. J. Microbiol. Res. 2, 67-72.

Fatem, S., Peday, M. H., \& Yowei, R. N. 2014. Ethno-biological notes on the Meyah Tribe from the Northern part of Manokwari, West Papua (catatan etnobiologi pada Suku Meyah di Pantai Utara Manokwari, Papua Barat). Jurnal Manusia Dan Lingkungan, 21(1): 121-127.

Folega, F., Zhang, C. Y., Samake, G., Kperkouma, W., Batawila, K., Zhao, X. H., \& Koffi, A. 2011. Evaluation of agroforestry species in potential fallows of areas gazetted as protected areas in North-Togo. Afr. J. Agric. Res, 6(12): 2828-2834.

Guevara, C. P. B., \& Garcia, M. M. 2018. Ethnobotanical practices of Matigsalug Tribe on medicinal plants at Barangay Baganihan, Marilog District, Davao City. Journal of Complementary and Alternative Medical Research, 6(3): 1-14.

Hadiah, J.T., Yuzammi, Y., \& Purnomo, D. W. 2019. Kajian habitat dan populasi pasak bumi (Eurycoma longifolia Jack.) di blok barat kawasan hutan konservasi PT Sabhantara Rawi Santosa, Kutai Timur, Kalimantan Timur. Buletin Kebun Raya, 22(1): 31-46. 
Handayani, S.K., \& Kunda, R.M. 2019. Identifikasi jenis-jenis tumbuhan sebagai pakan kuskus (Phalangeridae) asal Maluku di Taman Nasional Manusela bagian Utara Kabupaten Maluku Tengah. Jurnal Matematika, Sains, Dan Teknologi, 20(1): 919.

Hoa Hong Dao, T., \& Hölscher, D. 2015. Red-listed tree species abundance in montane forest areas with differing levels of statutory protection in north-western Vietnam. Tropical Conservation Science, 8(2): 479-490.

Hussein, M., \& Jamal, S. 2019. Microbial activity of Alstonia scholaris leaf extract against pathogenic microorganisms. Journal of Research in Biomedical Sciences, $1(1): 1-4$.

Hwang, C. S., Santhanam, U., Baldys, J. I., \& Lyga, J. W. 2016, May 24. Use of Melicope extracts to improve conditions caused by excess lipids. Google Patents.

[IUCN] International Union for Conservation of Nature Resources. 2019. The IUCN red list of threatened species accessed from http://www.iucnredlist.org/search [diunduh dan diakses 2 Mei 2019].

Kartikasari, S. N., Marshall, A. J., \& Beehler, B. (eds.). 2012. Ekologi Papua. Yayasan Pustaka Obor Indonesia. pp. 98-101.

Khan, M. R., Kihara, M., \& Omoloso, A. D. 2002. Antimicrobial activity of Calophyllum soulattri, Fitoterapia, 73: 741-743.

Komara, L. L., Choesin, D. N., \& Syamsudin, T. S. 2016. Plant diversity after sixteen years post coal mining in East Kalimantan, Indonesia. Biodiversitas Journal of Biological Diversity, 17(2): 531-538.

Kukla, J., Whitfeld, T., Cajthaml, T., Baldrian, P., Veselá-Šimáčková, H., Novotný, V., \&

Frouz, J. 2019. The effect of traditional slash-and-burn agriculture on soil organic matter, nutrient content, and microbiota in tropical ecosystems of Papua New Guinea. Land Degradation \& Development, 30(2): 166-177.

Lekitoo, K., \& Khayati, L. 2019. Woody diversity plant and non-timber forest products potential in protected forest area of protected forest management unit model in Sorong City, West Papua. In Prosiding Seminar Nasional Masyarakat Biodiversitas Indonesia (Vol. 5, pp. 294-298).

Lim, C.-K., Hemaroopini, S., Say, Y.-H., \& Jong, V. Y.-M. 2017. Cytotoxic compounds from the stem bark of Calophyllum soulattri. Natural Product Communications, 12(9): 1469-1471.

Minarti, M., Mulyani, H., Megawati, M., Meilawati, L., Fajriah, S., \& Widiyarti, G. 2018. Isolation of stigmasterol and 20-epibryonolic acid from Tetrameles nudiflora stem bark. In AIP Conference Proceedings (Vol. 2024, p.1-6). AIP Publishing.

Murdjoko, A., Marsono, D., Sadono, R., \& Hadisusanto, S. 2016. Tree association with Pometia and its structure in logging concession of South Papua forest. Jurnal Manajemen Hutan Tropika, 22(3): 180-191.

Narayanan, N. K., Kunimasa, K., Yamori, Y., Mori, M., Mori, H., Nakamura, K., Miller, G., Manne, U., Tiwari, A.K., \& Narayanan, B. 2015. Antitumor activity of melinjo (Gnetum gnemon L.) seed extract in human and murine tumor models in vitro and in a colon-26 tumor-bearing mouse model in vivo. Cancer Medicine, 4(11): 17671780.

Ong, H. C., Silitonga, A. S., Masjuki, H. H., Mahlia, T. M. I., Chong, W. T., \& Boosroh, M. H. 2013. Production and comparative fuel properties of biodiesel from nonedible oils: Jatropha curcas, Sterculia foetida and Ceiba pentandra. Energy Conversion and Management, 73, 245-255.

Paijmans, K. 1976. New Guinea Vegetation. (K. Paijmans, Ed.) (1st ed.). Canberra: Canberra, ACT: Common Wealth Scientific and Industrial Research Organization. pp. 49-51. 
Pannell, C.M. 1998. Aglaia odorata. The IUCN Red List of threatened species 1998. http://dx.doi.org/10.2305/IUCN.UK.1998.RLTS.T34913A9896864.en [diunduh 17 April 2019].

Pereki, H., Wala, K., Thiel-clemen, T., Bessike, M. P. B., Zida, M., Dourma, M., Batawila, K., \& Akpagana, K. 2013. Woody species diversity and important value indices in dense dry forests in Abdoulaye Wildlife Reserve (Togo, West Africa). International Journal of Biodiversity and Conservation, 5(6): 358-366.

Robiansyah, I. 2018. Diversity and biomass of tree species in Tambrauw, West Papua, Indonesia. Biodiversitas Journal of Biological Diversity, 19(2): 377-386.

Sanchez, P. A. 1999. Improved fallows come of age in the tropics. Agroforestry Systems, 47(1-3): 3-12.

Sinery, A. S., Farida, W. R., \& Wai, J. M. 2016. The population of spotted cuscus (Spilocuscus maculatus) and its habitat carrying capacity in Numfor Island, Papua, Indonesia. Biodiversitas Journal of Biological Diversity, 17(1): 315-321.

Sirami, E. V., Marsono, D., Sadono, R., \& Imron, M. A. 2019. Typology of native species as the shade tree for merbau (Intsia bijuga) plantations in Papua, Indonesia based on ecological species group. Biodiversitas Journal of Biological Diversity, 20(1), 43-53.

Susanto, S. A., Budirianto, H. J., \& Maturbongs, A. C. 2018. Komposisi Jenis Tumbuhan di Tanah Alluvial Lahan Bera Diperkaya Womnowi, Distrik Sidey Manokwari. In Prosiding Seminar Nasional MIPA UNIPA (Vol. 3, pp. 22-32).

Susanto, S.A., Budirianto, H.J., dan Maturbongs, A.C. 2019. Suhu dan kelembaban berdampak pada produktivitas serasah basah vegetasi dominan di lahan bera Womnowi Distrik Sidey Manokwari Papua Barat. BIOMA:Jurnal Biologi Makassar $4(1): 1-10$.

Vink, W. (1998). Notes on some lowland rainforests of the Bird's Head peninsula, Irian Jaya. Bird's Head Approaches. Modern Quaternary Research in Southeast Asia, 15, 91-109.

[WCMC] World Conservation Monitoring Centre. 1998. Intsia bijuga. The IUCN Red List of Threatened Species 1998: e.T32310A9694485. http://dx.doi.org/10.2305/IUCN.UK.1998.RLTS.T32310A9694485.en [diunduh 2 Mei 2019].

Wu, S.-Y., Fu, Y.-H., Zhou, Q., Bai, M., Chen, G.-Y., Han, C.-R., \& Song, X.-P. 2018. A new dihydrochalcone glycoside from the stems of Homalium stenophyllum. Natural Product Research, 32(8): 953-958.

Yirdaw, E., Monge, A. M., Austin, D., \& Toure, I. 2019. Recovery of floristic diversity, composition and structure of regrowth forests on fallow lands: implications for conservation and restoration of degraded forest lands in Laos. New Forests, 1-20. 